\title{
REPRESENTASI MAKNA VERBAL DAN FUNGSI DALAM PEPATAH BAHASA KAILI DIALEK RAI DI SULAWESI TENGAH
}

\section{REPRESENTATION OF VERBAL MEANINGS AND FUNCTIONS OF KAILI LANGUAGE ADAGES IN RAI DIALECT AT CENTRAL SULAWESI}

\author{
Ulinsa $^{1^{*}}$ \\ ${ }^{1}$ Fakultas Keguruan dan Ilmu Pendidikan Universitas Tadulako \\ *Corresponding Author: ulinsa.bahasaindonesia@gmail.com \\ Informasi Artikel: \\ Dikirim: 17/5/2020; Direvisi: 20/6/2020; Diterima: 1/7/2020
}

\begin{abstract}
The formulation of the problem in this study, namely (1) what verbal meanings are represented in the proverb in the Kaili language, Rai dialect? and (2) what function is represented in the proverb of Kaili in the Rai dialect? The research objectives, namely (1) to describe the representation of verbal meanings in the proverbial Kaili language in the Rai dialect and (2) to describe the functions represented in the proverb in the Kaili language in the Rai dialect. This type of research is qualitative with the method used is descriptive. The research was conducted in Tondo Village, Sirenja District, Donggala Regency, Central Sulawesi Province. The data source is in the form of oral sources (determining the informant). Data collection techniques in this study used field research techniques, namely observation, interviews, recording and recording. The data analysis technique is done by; collect data, reduce data, present data, and conclude. The results showed that in the proverb of the ethnic Kaili, the amount of 16 represented two forms of meaning, namely denotative meaning and connotative meaning.
\end{abstract}

Keywords: ethnic Kaili, proverb, representation, verbal meaning

Abstrak

Rumusan masalah dalam penelitian ini, yakni (1) makna verbal apa saja yang terepresentasi dalam pepatah bahasa Kaili dialek Rai? dan (2) fungsi apa yang terepresentasi dalam pepatah bahasa Kaili dialek Rai? Tujuan penelitian, yakni (1) untuk mendeskripsikan representasi makna verbal dalam pepatah bahasa Kaili dialek Rai dan (2) mendeskripsikan fungsi yang terepresentasi dalam pepatah bahasa Kaili dialek Rai. Jenis penelitian adalah kualitatif dengan metode yang digunakan adalah deskriptif. Penelitian dilaksanakan di Desa Tondo, Kecamatan Sirenja, Kabupaten Donggala, Provinsi Sulawesi Tengah. Sumber data berupa sumber lisan (menentukan informan). Teknik pengumpulan data dalam penelitian ini menggunakan teknik penelitian lapangan, yaitu observasi, wawancara, perekaman dan pencatatan. Teknik analisis data dilakukan dengan cara; mengumpulkan data, mereduksi data, menyajikan data, dan menyimpulkan. Hasil penelitian menunjukkan bahwa dalam pepatah etnik Kaili yang berjumlah 16 merepresentasikan dua bentuk makna, yakni makna denotatif dan makna konotatif.

Kata kunci: etnik Kaili, pepatah, representasi, makna verbal 


\section{PENDAHULUAN}

Indonesia memiliki kekayaan budaya juga bahasa. Bahasa daerah menjadi salah satu kekayaan yang dimiliki oleh Indonesia yang merupakan suatu kebanggaan, di sisi lain juga menjadi tugas yang tidak ringan, terutama apabila memikirkan bagaimana cara melindungi, menggali manfaat, dan mempertahankan keberagamannya. Indonesia disegani oleh bangsa lain karena kekayaan alam dan kemajemukannya. Salah satu menjadi ciri khas kemajemukan itu dapat dilihat dari beragam suku, bahasa, dan agama. Keberagaman itu dapat dilihat dari bahasa daerah sebagai identitas diri penuturnya.

Pengaturan tentang bahasa daerah dalam peraturan perundang-undangan bukanlah hal utama, kecuali dalam beberapa perda. Pengaturan penggunaan bahasa daerah menjadi pelengkap pengaturan tentang bahasa Indonesia atau bahasa Negara. Dalam Undang-Undang nomor 20 Tahun 2003 tentang Sistem Pendidikan Nasional termasuk Undang-Undang Nomor 4 Tahun 1950 jo Undang-Undang Nomor 12 Tahun 1945 dan Undang-Undang Nomor 2 Tahun 1989 yang menjadi cikal bakal Undang-Undang Nomor 20 Tahun 2003, yakni penggunaan bahasa daerah diatur sebagai pelengkap penggunaan bahasa Indonesia yang diwajibkan dalam penyelenggaraan pendidikan nasional di Indonesia. Bahasa daerah boleh digunakan pada tahap awal pendidikan untuk menyampaikan pengetahuan dan keterampilan tertentu.

Penggunaan bahasa daerah sebagai bahasa pengantar di kelas menjadi bukti bahwa sesungguhnya Indonesia sejak tahun 1950 telah menerapkan prinsip EFA (education for all) yang dicetuskan oleh UNESCO baru pada tahun 1990-an. Penggunaan bahasa daerah sebagai bahasa pengantar dunia pendidikan merupakan upaya menjangkau peserta didik yang belum mampu mengikuti pelajaran yang disampaikan dalam bahasa Indonesia. Hal itu sekaligus juga menjadi bukti bahwa Indonesia juga menerapkan program MLE (multilingual education), yaitu program pendidikan yang memanfaatkan bahasa pertama sebagai bahasa pengantar di peringkat awal, yakni kelas rendah sebelum lanjut pada kelas tinggi kemudian beralih ke bahasa nasional.

Perlindungan terhadap bahasa daerah didasarkan pada amanat Pasal 32 Ayat 2 UUD 1945, yang menyatakan bahwa negara menghormati dan memelihara bahasa daerah sebagai kekayaan budaya nasional. Dengan ayat itu, negara memberi kesempatan dan keleluasaan kepada masyarakat untuk melestarikan dan mengembangkan bahasanya sebagai bagian dari kebudayaannya masing-masing. Selain itu, negara memajukan kebudayaan nasional Indonesia di tengah peradaban dunia dengan menjamin kebebasan masyarakat dalam memelihara dan mengembangkan nilai-nilai budayanya.

Kebebasan yang diberikan UUD 1945 bukan berarti kebebasan yang tanpa pembatasan karena hingga pada batas tertentu pengembangan dan penggunaan bahasa daerah pasti akan berbenturan dengan ketentuan lain. Untuk keperluan bernegara, kebebasan penggunaan bahasa daerah yang diamanatkan itu akan terbentur dengan batas penggunaan bahasa negara. Untuk keperluan hidup dan pergaulan sosial, keleluasaan penggunaan satu bahasa daerah harus juga menghormati penggunaan bahasa daerah lain. Dengan kata lain, keleluasaan penggunaan dan pengembangan bahasa daerah dalam banyak hal juga tidak boleh melanggar norma "sosial" dan norma perundang-undangan yang ada. 
Terkait dengan peraturan pemerintah sebagaimana diuraikan di atas, penelitian ini dilakukan sebagai bentuk tindak lanjut implementasi peraturan pemerintah republik Indonesia dan peraturan pemerintah daerah tersebut. Bahasa daerah sebagai warisan leluhur yang secara turun-temurun diwariskan kepada masyarakat sebagai mahluk sosial. Keberadaannya sebagai bahasa daerah memiliki fungsi sebagai pembentuk kepribadian suku bangsa, peneguh jati diri kedaerahan, dan sarana pengungkapan serta pengembangan sastra dan budaya daerah dalam bingkai keindonesiaan. Di lain sisi, bahasa daerah berfungsi pula sebagai sarana komunikasi dalam keluarga dan masyarakat daerah, bahasa media massa lokal, sarana pendukung bahasa Indonesia, dan sumber pengembangan bahasa Indonesia.

Berdasarkan fungsi bahasa daerah, penelitian ini dilakukan dengan sasaran bahasa daerah Kaili yang penuturnya berada di wilayah Kabupaten Donggala, Provinsi Sulawesi Tengah. Bahasa Kaili juga memiliki beragam dialek. Di antaranya dialek Ledo, Rai,Tara, Da'a, Unde, dan dialek Doi. Sejalan dengan pernyataan di atas, dialek menurut Meilet (dalam Karim, 2012:7) merupakan seperangkat bentuk ujaran lokal yang berbeda dengan ciri-ciri umum dan lebih saling mirip dengan bentuk ujaran yang lain dari bahasa yang sama. Dengan demikian, dialek inilah yang menjadi pembeda suku Kaili yang mendiami suatu wilayah tertentu.

To Kaili atau orang Kaili memiliki pesan budaya yang sarat akan nilai-nilai yang tertuang dalam ujaran berupa ungkapan berbentuk pepatah. Pepatah yang diujarkan digunakan untuk menasihati, mendidik, mengingatkan, menyuruh, menghibur, melarang, memuji dan bahkan menyindir. Ujaran-ujaran dalam ungkapan berbentuk pepatah yang dimaksud dapat dijadikan alat untuk pembelajaran pendidikan karakter di sekolah dengan menyisipkan pepatah dalam bahasa Kaili dalam proses pembelajaran serta pola asuh di lingkungan keluarga dan masyarakat.

Pepatah yang hidup berkembang pada masyarakat suku Kaili umumnya disampaikan secara lisan. Ungkapan berbentuk pepatah memiliki bentuk-bentuk dalam sastra lisan. Sastra lisan adalah bagian dari tradisi yang berkembang secara lisan di tengah masyarakat yang menggunakan bahasa sebagai media utama. Sastra lisan ini muncul dan berkembang dimasyarakat sebelum sastra tulis.

Sama halnya di dalam bahasa daerah, pepatah juga dituturkan untuk mengkiaskan suatu maksud agar seseorang yang menjadi topik pembicaraan tidak merasa bahwa dirinyalah yang sedang diperbincangkan. Pepatah dan bahasa daerah memiliki keterkaitan yang sangat erat. Sebab bahasa daerah adalah bahasa yang memiliki nilai kesopansantunan yang tinggi. Oleh karena itu, masyarakat pengguna bahasa daerah kerap menggunakan ungkapan dalam berkomunikasi. Contoh ungkapan dalam bahasa Kaili dialek Rai "daa saridali ue naongamo". Ungkapan ini bermakna denotasi "air masih sampai di mata kaki, tetapi sudah tenggelam". Namun, ungkapan tersebut memiliki makna kias atau makna konotasi yaitu "seseorang yang sombong padahal ia belum sukses". Contoh selanjutnya, "tau na'pii”. Ungkapan ini bermakna denotasi "orang sempit". Namun memiliki makna konotasi "orang yang pelit".

Berdasarkan uraian yang telah dipaparkan pada bagian latar belakang, yang menjadi permasalahan dalam penelitian ini sebagai berikut: (1) makna verbal apa sajakah yang 
terepresentasi dalam pepatah bahasa Kaili dialak Rai? dan (2) fungsi apa sajakah yang terepresentasi dalam pepatah bahasa Kaili dialek Rai?

Selanjutnya dipaparkan konsep-konsep teoretik yang menjadi acuan dalam kajian ini. Makna adalah arti atau maksud yang terkandung dalam suatu kata. Makna merupakan aspek yang menimbulkan reaksi dan pengertian tertentu dalam pikiran pendengar atau pembaca sesuai dengan bahasa yang telah disepakati oleh masyarakat pengguna bahasa yang berada di wilayah tertentu. Istilah 'makna' dijelaskan dalam Kamus Besar Bahasa Indonesia adalah arti atau maksud. Menurut Grice (dalam Aminuddin, 2011:52 - 53) makna adalah hubungan antara bahasa dengan dunia luar yang telah disepakati bersama oleh para pemakai bahasa sehingga dapat saling dimengerti. Makna adalah hasil hubungan antara bahasa dan dunia luar yang terjadi karena kesepakatan para pemakai untuk menyampaikan informasi sehingga dapat saling dimengerti.

Jadi, berdasarkan uraian tersebut dapat disimpulkan bahwa makna adalah arti suatu tuturan atau bahasa yang berkaitan dengan konteks luar dan terjadi karena kesepakatan dari pengguna bahasa tersebut. Contoh, benda yang biasa digunakan untuk makan dan sebagai pengganti tangan dalam mengambil sesuatu, terbuat dari aluminium, besi dan plastik telah disepakati bahwa namanya sendok. Namun, jika hal itu belum disepakati dan setiap orang memberi makna sesuai dengan kemauan masing-masing bisa jadi benda tersebut diberi nama yang lain. Oleh karena itu, komunikasi akan terjalin dengan baik jika ada kesepahaman makna bahasa yang disampaikan oleh penutur dan lawan tutur baik secara lisan maupun tertulis.

Makna verbal adalah arti kata-kata yang dilisankan atau dituliskan yang berisi ungkapan perasaan, emosi, pemikiran, gagasan, insformasi, dll. Makna verbal dapat berbentuk makna konotasi dan makna denotatif. Secara leksikal makna terbagi menjadi dua bagian, yakni makna tersurat dan makna tersirat. Makna tersurat adalah makna yang nyata atau yang tertulis atau biasa disebut dengan makna denotasi. Makna tersirat adalah makna yang tersembunyi dibelakang apa yang diucapkan atau dituliskan, biasa juga disebut dengan makna konotasi.

Peribahasa adalah ayat atau kelompok kata yang mempunyai susunan yang tetap dan mengandung pengertian tertentu. Peribahasa merupakan kalimat atau kelompok perkataan yang tetap susunannya dan biasanya mengkiaskan sesuatu maksud yang tentu. Dalam peribahasa termasuk juga ungkapan, bidal, dan perumpamaan.

Peribahasa merupakan alat pewaris nilai-nilai budaya lokal yang secra turun-temurun telah banyak mengalami perubahan dalam penerapannya. Dari generasi ke generasi peribahasa berfungsi memberi nasihat, teguran dan sindiran. Beberapa peribahasa merupakan perumpamaan yaitu perbandingan makna yang sangat jelas karena ia didahului oleh perkataan seolah-olah, ibarat, bak, seperti, laksana, macam, bagai dan umpama. Fungsi dari peribahasa seperti juga foklor lisan pada umumnya, yakni sebagai sistem proyeksi, sebagai alat pengesahan pranata-pranata dan lembaga kebudayaan, sebagai alat pendidikan, sebagai alat pemaksa dan pengawas norma-norma masyarakat agar selalu dipatuhi Bascom.

Peribahasa juga merupakan ungkapan yang walaupun tidak langsung namun secara tersirat menyampaikan suatu hal yang dapat dipahami oleh pendengarnya atau pembacanya karena sama-sama hidup dalam ruang lingkup budaya yang sama. Persamaan ruang lingkup 
budaya yang sama sangat berpengaruh penting dalam penggunaan peribahasa. Sebab peribahasa terlahir dari kebiasaan-kebiasaan masyarakat bertutur dan telah menjadi budaya dalam suatu ruang lingkup tertentu.

Peribahasa juga sebagai alat komunikasi terutama dalam hal pengendalian masyarakat yang secara konkret untuk mengkritik seseorang yang telah melanggar norma masyarakat. Mencelah seseorang dengan mempergunakan peribahasa lebih mudah diterima dan lebih terarah pada sasarannya daripada celaan langsung. Jadi, peribahasa adalah kelompok kata yang tersusun secara tetap dan biasanya mengiaskan suatu maksud tertentu dan berfungsi untuk memberi nasihat, teguran dan sindiran.

Peribahasa dalam suatu bangsa sangat dipengaruhi oleh pikiran, budaya, serta pengalaman yang ada pada suatu bangsa. Masyarakat kecamatan Sirenja terkenal dengan sopan santun serta kecenderungan berbasa-basi. Bahasa Kaili pun mengikuti pola tingkah orang Kaili yang cenderung menggunakan ungkapan yang tidak langsung dan bermakna mendalam. Contohnya adalah peribahasa, yang merupakan salah satu alat untuk menyampaikan maksud secara tidak langsung dalam bahasa Kaili. Menurut Kusmayadi (Chaer, 2008:78-79), peribahasa itu adalah kalimat atau kelompok perkataan yang tetap susunannya dan biasanya mengkiaskan sesuatu hal. Menurut bentuknya peribahasa dapat dibedakan atas: (1) pepatah, (2) perumpamaan, dan (3) semboyan. Dari tiga bagian peribahasa tersebut, penelitian ini difokuskan pada bentuk pepatah.

Pepatah adalah salah satu bentuk ungkapan yang berisi nasihat atau ujaran dari orang tua. Pepatah merupakan peribahasa yang mengandung nasehat dan sebagainya; perkataan ujaran orang tua-tua. Pepatah ialah peribahasa yang mengandung nasihat (Badudu, 1986:6). Dalam bahasa Kaili pepatah biasanya ditandai dengan kata nemo yang artinya 'jangan'. Masyarakat penutur bahasa Kaili khususnya orang tua memberi nasihat dengan cara melarang atau memperingati. Jadi, pepatah adalah jenis peribahasa yang digunakan oleh masyarakat penutur bahasa Kaili, khususnya para orang tua untuk memberikan nasehat kepada anakanaknya atau kepada seseorang yang dianggap telah melanggar norma kehidupan masyarakat.

Pepatah didefenisikan sebagai jenis peribahasa yang mengandung nasihat, peringatan, atau sindirian. Ciri-ciri pepatah dalam bahasa Kaili dialek Rai biasanya ditandai dengan kata awalan nemo ‘jangan'. Pepatah mengandung nilai-nilai norma yang berlaku di dalam kehidupan sehari-hari. Pepatah juga biasa disebut Undang-Undang di dalam masyarakat. Pepatah digunakan orang tua untuk mengatur pola tingkah laku manusia dalam kehidupan sosial bermasyarakat. Pepatah sering digunakan oleh para orang tua untuk menasehati dan memberi wejangan terhadap anak muda yang tengah berbuat salah, atau pun yang datang untuk meminta petuah-petuah dari para orang tua. Dalam bahasa Kaili dialek Rai, pepatah berkembang dengan tradisi lisan. Artinya, tidak ada dokumentasi tertulis dari suatu pepatah dalam masyarakat. Pepatah hanya dilisankan oleh para orang tua dari mulut ke mulut sehingga membudidaya dan menjadi suatu kebiasaan di dalam masyarakat. Begitulah pepatah berkembang dan dapat tumbuh dari waktu ke waktu hingga sekarang ini. Contoh: "Nemo, daa saridali ue maongamo". Makna denotasinya "Jangan air masih sampai di mata kaki, sudah tenggelam". Makna kiasannya "angan baru berjaya sedikit, sudah bersifat sombong". 


\section{METODE}

Kegiatan penelitian ini dilaksanakan di Kecamatan Sirenja, Kabupaten Donggala. Penelitian ini tergolong penelitian kualitatif model interaktif dari Miles dan Hubermen (Sugiyono, 2014:91). Penelitian kualitatif ini dipergunakan untuk menafsirkan, mengartikan, menggambarkan serta mendeskripsikan makna verbal yang terepresentasi dalam pepatah bahasa Kaili dialek Rai. Lokasi penelitian merupakah daerah penutur asli bahasa Kaili dialek Rai. Mereka adalah informan penelitian ini. Instrumen penelitian adalah diri peneliti yang terjun langsung ke masyarakat untuk mengumpulkan data. Kegiatan pengumpulan data dilakukan dengan metode pengamatan dan wawancara. Kegiatan pengamatan dan wawancara disertai dengan perekaman dan pencatatan data. Tahapan analisis data dalam penelitian ini meliputi: pengumpulan data, reduksi data, penyajian data, dan penarikan kesimpulan.

\section{HASIL DAN PEMBAHASAN}

Pada sub-bab ini diurakan hasil dan pembahasan terkait dengan makna verbal dan fungsi makna yang terepresentasi dalam pepatah bahasa Kaili dialek Rai. Adapun perwujudan makna verbal dan fungsi makna yang terepresentasi dalam pepatah bahasa Kaili dialek Rai akan diuraikan sebagai berikut.

\section{Makna Verbal yang Terepresentasi pada Pepatah dalam Bahasa Kaili Dialek Rai}

Bagian ini diuraikan pembahasan hasil penelitian, yakni 16 pepatah dalam bahasa Kaili dialek Rai. Dari 16 pepatah yang diperoleh dalam penelitian ini dibahasa berdasarkan dua makna verbal, yakni makna denotative dan makna konotatif. Lebih jelasnya perhatikan uraian berikut ini.

Data (1): Ane mojarita nemo momi risumba pai riate.

Makna Denotasi: Kalau berbicara jangan manis dibibir, pahit dihati.

Makna Konotasi: Lain diucapkan oleh mulut, lain pula yang ada didalam hati.

Data (2): Agina mainga, ne maonga.

Makna Denotasi: Lebih baik berhati-hati, jangan tenggelam.

Makna Konotasi: Lebih baik berhati-hati sebelum terjadi sesuatu.

Data (3): Nemo matuari sumba.

Makna Denotasi: Jangan bertingkahlaku cerewet.

Makna konotasi: Jangan sembarang berbicara.

Data (4): Nemo mareso mpo yalu.

Makna Denotasi: Jangan hanya capek bagai alu.

Makna Konotasi: Jangan hanya capek percuma.

Data (5): Ane malau risakampuna, nemo moura ane rai nte toya.

Makna Denotasi: Kalau ke kampong orang, jangan pulang tanpa ayunan.

Makna Konotasi : Kalau hendak merantau, menikahlah dengan masyarakat pribumi.

Data (6): Nemo mangoli taveve rilara karu.

Makna Denotasi: Jangan membeli kucing didalam karung.

Makna Konotasi: Jangan membeli sesuatu yang tidak pasti karena terlalu percaya.

Data (7): Nemo mosondu uta vai. 
Makna Denotasi: Jangan menyendok sayur basi.

Makna Konotasi: Hati-hati didalam memilih pendamping hidup, jangan sampai mendapatkan bekas orang lain.

Data (8): Ane malau risakampuna nemo mokura kodi.

Makna Denotasi: Kalau pergi ke kampung orang jangan, jangan belangga kecil.

Makna Konotasi: Jika ke kampung orang lain, janganlah jadi orang yang mudah tersinggung dengan perkataan orang.

Data (9): Nemo mangganasipa mata, rakalingasimo mate.

Makna Denotasi: Jangan setelah melihat mata, sudah dilupakan mati.

Makna Konotasi: Setelah diberikan Tuhan derajat yang tinggi (terpandang) di dunia, sudah dilupakan akhirat (mati).

Data (10): Ane mojarita, rapomeili bengo.

Makna Denotasi: Kalau berbicara, tenggok kebelakang.

Makna Konotasi: Kalau berbicara hendaklah berkaca pada diri sendiri.

Data (11): Agina malalo bangko, aga ne masala ganggo.

Makna Denotasi: Lebih baik tidak mempunyai keturunan, asal jangan salah ambil.

Makna Konotasi: Lebih baik jadi gadis/jejaka tua, asal jangan salah tujuan.

Data (12): Nemo mavatu ntiongu.

Makna Denotasi: Jangan keras seperti batu yang bulat (bentuknya).

Makna Konotasi: Jangan nakal sekali dan keras kepala.

Data (13): Ane matuvu ringapa ntau, nemo ntani motungoa.

Makna Denotasi: Kalau hidup di negeri orang jangan terlalu menengadah.

Makna Konotasi: Kalau hidup dirantau orang, jangan suka menyombongkan diri.

Data (14): Nemo mamomipa, raome nturusimo.

Makna Denotasi: Jangan karena manis ditelan terus saja.

Makna Konotasi: Jangan termakan rayuan sudah menuruti perkataannya"

Data (15): Ane majadi manggubine nemo mandate sumba.

Makna Denotasi: Kalau jadi perempuan, jangan bermulut panjang

Makna Konotasi : Kalau jadi perempuan, jangan suka membawa bicara

Data (16): Isema mandiu, etu maobe.

Makna Denotasi: Siapa mandi, itulah basah

Makna Konotasi:Siapa yang berbuat salah dia sendiri yang akan menerima ganjarannya.

\section{Fungsi yang Terepresentasi pada Pepatah Bahasa Kaili Dialek Rai}

Pada sub ini diuraikan fungsi makna yang terepresentasi dalam 16 pepatah bahasa Kaili dialek Rai.

Data (1): Ane mojarita nemo momi risumba pai riate.

Makna Denotasi: Kalau berbicara jangan manis dibibir, pahit dihati

Makna Konotasi: Lain diucapkan oleh mulut, lain pula yang ada didalam hati

Fungsi: Pepatah ini disampaikan oleh orang tua, biasanya digunakan saat orang tua marah ketika si anak melakukan pekerjaan dengan muka yang cemberut. Orang tua beranggapan anak tersebut melakukan pekerjaan dengan ketidakikhlasan dalam hati. 
Jika diperintah ia mengatakan ie 'iya', tetapi bekerja dengan mengerutu dalam hati. Oleh sebab itu berpengaruh terhadap raut wajahnya.

Data (2): Agina mainga, ne maonga.

Makna Denotasi: Lebih baik berhati-hati, jangan tenggelam.

Makna Konotasi: Lebih baik berhati-hati sebelum terjadi sesuatu.

Fungsi: Pepatah ini diungkapkan orang tua kepada anaknya yang sembrono dalam melakukan sesuatu. Pepatah ini digunakan ketika hendak mengingatkan kepada si anak agar selalu berhati-hati sebelum terjadi sesuatu yang tidak diinginkan.

Data (3): Nemo matuari sumba kapeaba-abo.

Makna Denotasi: Jangan bertingkah laku cerewet lalu nyeletuk.

Makna konotasi: Jangan sembarang berbicara dan menyambung pembicaraan orang tua.

Fungsi: Pepatah ini diungkapkan orang tua kepada anaknya yang suka berbicara meniru kebiasaan orang tua yang belum seumuran dengannya. Ungkapan ini biasanya digunakan ketika orang tua marah jika ada anak yang suka berkumpul dan mendengarkan pembicaraan orang tua yang belum pantas didengarkanya, lalu ditirunya.

Data (4): Nemo mareso mpo yalu.

Makna Denotasi: Jangan hanya capek bagai alu.

Makna Konotasi: Jangan hanya capek percuma.

Fungsi: Pepatah ini diungkapkan orang tua kepada anaknya yang bekerja pada orang lain. Ungkapan ini biasanya dikemukakan orang tua kepada si anak ketika mendengar upah kerja yang diperoleh si anak tidak sesuai dengan pekerjaan yang dilakukannya. Oleh karena itu, orang tua menasehati dengan mengungkapkan pepatah ini. Secara tidak langsung, orang tua menyuruh kepada si anak agar meninggalkan pekerjaannya.

Data (5): Ane malau risakampuna, nemo moura ane rai nte toya.

Makna Denotasi: Kalau ke kampong orang, jangan pulang tanpa ayunan

Makna Konotasi: Kalau hendak merantau, menikahlah dengan masyarakat pribumi.

Fungsi: Pepatah ini diungkapkan orang tua kepada anaknya yang hendak merantau ke negeri orang. Pepatah ini biasanya diungkapkan orang tua pada saat terakhir sebelum si anak berangkat. Ungkapan ini secara tidak langsung bermaksud mengatakan kepada si anak bahwa janganlah pulang jika engkau belum sukses dan menikah.

Data (6): Nemo mangoli taveve rilara karu.

Makna Denotasi: Jangan membeli kucing didalam karung.

Makna Konotasi: Jangan membeli sesuatu yang tidak pasti karena terlalu percaya.

Fungsi: Pepatah ini biasanya diungkapkan orang tua kepada anak lelakinya saat ia hendak meminta izin untuk meminang seorang gadis yang disukainya hanya karena mendengar cerita dari orang bahwa gadis tersebut berkelakuan baik. Ungkapan ini secara tidak langsung menasehati kepada sang anak agar janganlah salah memilih.

Alangkah baiknya lihatlah sendiri terlebih dahulu, agar tidak rugi.

Data (7): Nemo mosondu uta vai.

Makna Denotasi: Jangan menyendok sayur basi 
Makna Konotasi: Hati-hati didalam memilih pendamping hidup, jangan sampai mendapatkan bekas orang lain.

Fungsi: Pepatah ini biasanya diungkapkan orang tua kepada anak lelakinya yang ingin menikah dengan wanita yang belum ia kenali dengan baik. Agar si anak lelaki mencari tau terlebih dahulu latar belakang wanita tersebut, agar tidak mendapatkan bekas dari orang lain.

Data (8): Ane malau risakampuna nemo mokura kodi.

Makna Denotasi: Kalau pergi ke kampung orang, jangan berbelangga kecil.

Makna Konotasi: Jika ke kampung orang lain, janganlah jadi orang yang mudah tersinggung dengan perkataan orang.

Fungsi: Pepatah ini diungkapkan orang tua kepada anaknya yang hendak merantau ke kampung orang lain, agar anaknya tidak memiliki sifat yang kecil hati atau mudah tersinggung ketika berada di kampung orang lain, meskipun bertemu dengan orangorang baru di sekitarnya.

Data (9): Nemo mangganasipa mata, rakalingasimo mate.

Makna Denotasi: Jangan setelah melihat mata, sudah dilupakan mati.

Makna Konotasi: Setelah diberikan Tuhan derajat yang tinggi (terpandang) di dunia, sudah dilupakan akhirat (mati).

Fungsi: Pepatah ini biasanya diungkapkan orang tua kepada anaknya yang tengah sukses, mendapat pekerjaan baru ataupun mendapatkan rezeki yang banyak. Nasehat ini diungkapkan orang tua agar anaknya tidak terlena dengan apa yang dimilikinya di dunia, serta selalu mengingat bahwa kematian itu pasti akan datang. Artinya, hidup di duniah harus menyeimbangkan dunia dan akhiraat.

Data (10): Ane mojarita, rapomeili bengo.

Makna Denotasi: Kalau berbicara, tenggok kebelakang

Makna Konotasi: Kalau berbicara hendaklah berkaca pada diri sendiri

Fungsi: Pepatah ini seringkali diungkapkan orang tua kepada siapa saja yang dianggapnya sombong ketika sedang berbicara. Pepatah ini mengkiaskan maksud agar ketika berbicara seseorang hendaklah melihat siapa dirinya dan bertanya pada diri sendiri pantaskah ia berbicara seperti itu.

Data (11): Agina malalo bangko, aga ne masala ganggo.

Makna Denotasi: Lebih baik tidak mempunyai keturunan, asal jangan salah ambil.

Makna Konotasi: Lebih baik menjadi perawan tua/jejaka tua, asal jangan salah pilih pasangan.

Fungsi: Pepatah ini diungkapkan orang tua kepada anak lelaki atau perempuannya yang terburu-buru untuk menikah. Pepatah ini mengiaskan maksud agar anak tersebut lebih baik menjadi perawan tua/jejaka tua asal jangan salah memilih pasangan hidup.

Data (12): Nemo mavatu ntiongu.

Makna Denotasi: Jangan seperti batu yang bulat (bentuknya)

Makna Konotasi: Jangan nakal sekali dan keras kepala.

Fungsi: Pepatah ini seringkali dinasehatkan kakek/nenek kepada cucu laki-lakinya. Pepatah ini mengkiaskan maksud si kakek/nenek agar tidak menyinggung perasaan menantunya. Bahwa ia hendak mengatakan kepada cucu lelakinya agar tidak nakal. 


\section{Data (13): Ane matuvu ringapa ntau, nemo ntani motungoa.}

Makna Denotasi: Kalau hidup di negeri orang jangan terlalu menengadah.

Makna Konotasi: Kalau hidup di rantau orang, jangan suka menyombongkan diri.

Fungsi: Pepatah ini diungkapkan orang tua kepada anak lelaki atau perempuanya yang hendak dibawah oleh menantunya ke kampung halamannya. Pepatah ini mengkiaskan maksud orang tua agar jangan menyombongkan diri jika hidup di kampung orang lain.

Data (14): Nemo mamomipa, raome nturusimo.

Makna Denotasi: Jangan karena manis ditelan terus saja

Makna Konotasi: Jangan mendengar rayuannya lalu dituruti/dipercaya.

Fungsi: Pepatah ini seringkali diungkapkan orang tua untuk menasihati anaknya agar menyaring informasi yang diterima dari orang-orang yang sudah sangat dekat dengannya. Ungkapan ini dikemukakan ketika anaknya sangat dekat dan percaya kepada seseorang. Pepatah ini mengkiaskan maksud orang tua agar anaknya tidak selalu percaya dengan orang, sekalipun orang-orang terdekatnya. Sebab musuh tidak selamanya terlihat buruk.

Data (15) Ane majadi manggubine nemo mandate sumba.

Makna Denotasi: Kalau jadi perempuan, jangan bermulut panjang

Makna Konotasi: Kalau jadi perempuan, jangan suka membawa bicara

Fungsi: Pepatah ini diungkapkan orang tua kepada anak perempuan yang senang berbincangbincang dengan teman-temannya. Ungkapan ini diungkapkan ketika anak perempuan sudah mulai bergaul dengan lingkungan masyarakat sekitarnya. Pepatah ini mengkiaskan maksud orang tua agar anak perempuannya jangan suka bergosip atau menyampaikan kabar-kabar yang belum pasti kebenarannya.

Data (16): Isema mandiu, etu maobe.

Makna Denotasi: Siapa mandi, itulah basah.

Makna Konotasi: Siapa yang berbuat salah dia sendiri yang akan menerima ganjarannya

Fungsi: Pepatah ini seringkali diungkapkan orang tua kepada anak laki-lakinya yang selalu mementingkan solidaritas pertemanan di atas keselamatan diri. Ungkapan ini dikemukakan orang tua saat anak lelakinya terlibat perkelahian dengan seseorang. Namun setelah ditelusuri lebih lanjut, ternyata anak lelaki tersebut hanya membantu temannya yang merupakan sumber dari permasalahan. Sebab terkadang anak lelaki di Kecamatan Sirenja ini sering berkelahi karena membela temannya, padahal temannya yang dibelanya justru yang bersalah. Jadi, pepatah ini mengkiaskan maksud orang tua agar siapa yang berbuat salah, cukup dialah yang menanggung akibatnya sendiri.

\section{SIMPULAN}

Berdasarkan hasil dan pembahasan di atas dapat disimpulkan bahwa Suku Kaili mempunyai bentuk peribahasa berupa pepatah yang lazim digunakan oleh penuturnya untuk menyampaikan sesuatu maksud atau tujuan dan digunakan secara spontan kepada pihak lawan tutur, sehingga pihak lawan tutur tergugah hatinya serta tidak mudah tersinggung dengan apa 
yang disampaikan oleh penutur. Selain itu, makna verbal yang terepresentasi dalam pepatah bahasa Kaili dialek Rai berupa makna denotasi dan makna konotasi, serta fungsi makna yang terepresentasi dalam pepatah bahasa Kaili dialek Rai berupa: nasihat, menyindir, memberi semangat, menghimbau, memberi amanat, dan pesan-pesan dari orang tua untuk anakanaknya.

Pepatah dalam bahasa Kaili dialek Rai merupakan bentuk peribahasa yang digunakan oleh masyarakat Suku Kaili dalam menyampaikan maksud atau tujuan tertentu dalam kegiatan bertutur. Pepatah masyarakat Suku Kaili merupakan bentuk kearifan lokal yang patut dipertahankan dan dikembangkan agar dapat berlangsung secara terus menerus bagi generasi muda. Saran yang disampaikan peneliti adalah sebagai berikut. (1) Mendorong upaya-upaya penelitian di bidang kebudayaan, sehingga pada penelitian berikutnya tradisi dan budaya dapat dilestarikan dan memiliki informasi yang dapat dipertanggungjawabkan kebenarannya pada generasi yang akan datang. (2) Meningkatkan kualitas bahan bacaan atau referensi, yang berbasis sastra lokal yang dapat dimanfaatkan dalam pembelajaran di sekolah yang memiliki kontribusi dalam pembelajaran pendidikan karakter. (3) Meningkatkan pembinaan masyarakat terhadap pentingnya makna dan fungsi pepatah melalui penelitian yang lebih mendalam di bidang sastra lisan masyarakat Kaili.

\section{DAFTAR PUSTAKA}

Aminuddin. 2011. Semantik: Pengantar Studi tentang Makna. Bandung: Sinar Baru.

Badudu, J. S. 1986. Sari Kesusastraan Indonesia. Bandung : Pustaka Prima

Chaer, Abdul. 2008. Pengantar Semantik Bahasa Indonesia. Jakarta: Rineka Cipta.

Sugiyono. 2014. Memahami Penelitian Kualitatif. Bandung: Alfabeta. 